\title{
Factors associated with knowledge about malaria prevention among women of reproductive age, Tete Province, Mozambique, 2019-2020
}

Gerson Afai ${ }^{1 *}$ (1), Erika Valeska Rossetto², Cynthia Semá Baltazar ${ }^{3}$, Baltazar Candrinho ${ }^{4}$, Abuchahama Saifodine ${ }^{5}$ and Rose Zulliger ${ }^{6}$

\begin{abstract}
Background: Mozambique is a malaria endemic country with an estimated prevalence of malaria in children 6-59 months old that is twice as high in rural areas (46.0\%) as in urban areas (18.0\%). However, only $46.0 \%$ of women aged 15-49 years had complete knowledge about malaria in 2018. This study aimed to identify the factors associated with malaria knowledge among women of reproductive age in a high malaria burden district.

Methods: Data from a cross-sectional study, using a population-based malaria research study in Mágoe District, 2019, were analysed. This analysis included women aged 15-49 years. A multivariate logistic regression model was developed to determine factors associated with complete knowledge of malaria that calculated adjusted odds ratio (aOR) and 95\% confidence interval (Cl) at a p $<0.05$ significance level. Complete malaria knowledge was defined as when a woman correctly identified: fever as a malaria symptom, mosquito bites as the means of malaria transmission, mosquito nets as a tool for malaria prevention, malaria as curable, and were able to name an anti-malarial.

Results: A total of 1899 women were included in this analysis. There was complete malaria knowledge among 49\% of the respondents. Seventy one percent mentioned fever as one of malaria symptoms, $92 \%$ mentioned mosquito bite as the cause of malaria infection, $94 \%$ identified that mosquito nets prevent malaria, 92\% agreed that malaria has cure, and $76 \%$ were able to name at least one anti-malarial medicine. In the multivariate analysis, the following characteristics were associated with significantly higher odds of having complete malaria knowledge: having a secondary school or above education level (adjusted Odds Ratio, $\mathrm{aOR}=2.5 \mathrm{Cl}$ [1.3-4.6] $\mathrm{p}=0.005$ ), being from the middle socioeconomic status group $(\mathrm{aOR}=1.5 \mathrm{Cl}[1.1-2.1] \mathrm{p}=0.005)$, being from older age group of $35-39(\mathrm{aOR}=1.9 ; \mathrm{Cl}[1.1-3.1]$ $\mathrm{p}<0.001$ ), having $1-2$ children ( $\mathrm{aOR}=1.8 ; \mathrm{Cl}[1.2-2.6] \mathrm{p}=0.003)$, and having interviews completed in Portuguese or Cinyungwe $(a \mathrm{OR}=2.3 ; \mathrm{Cl}[1.3-4.1] \mathrm{p}=0.004$ and $\mathrm{aOR}=2.1 ; \mathrm{Cl}[1.5-2.8] \mathrm{p}<0.001$, respectively).
\end{abstract}

Conclusion: Most women in this study had some malaria knowledge, but gaps in complete knowledge remained. In order to broaden knowledge, educational messages about malaria prevention should be more effectively targeted to reach younger, less-educated women and in non-dominant languages.

Keywords: Malaria, Health Knowledge, Risk Factors, Mozambique

*Correspondence: Gt.afai88@gmail.com

${ }^{1}$ Mozambique Field Epidemiology Training Programme, Instituto Nacional de Saúde, P.O. Box 264, Maputo, Mozambique

Full list of author information is available at the end of the article permits use, sharing, adaptation, distribution and reproduction in any medium or format, as long as you give appropriate credit to the original author(s) and the source, provide a link to the Creative Commons licence, and indicate if changes were made. The images or other third party material in this article are included in the article's Creative Commons licence, unless indicated otherwise in a credit line to the material. If material is not included in the article's Creative Commons licence and your intended use is not permitted by statutory regulation or exceeds the permitted use, you will need to obtain permission directly from the copyright holder. To view a copy of this licence, visit http://creativecommons.org/licenses/by/4.0/. The Creative Commons Public Domain Dedication waiver (http://creativeco mmons.org/publicdomain/zero/1.0/) applies to the data made available in this article, unless otherwise stated in a credit line to the data. 


\section{Background}

Worldwide, there has been remarkable progress in reducing malaria cases and deaths over the past decades as shown by the decrease from 238 million global cases in 2000 to 228 million cases in 2019 [1]. This reduction in transmission has been accompanied by a decrease in deaths from 736,000 in 2000 to 409,000 in 2019 [1]. Despite this progress, the World Health Organization (WHO) African Region continues to have the highest global malaria burden, representing 94.0\% of global cases, and Mozambique is among the top five countries with $5.0 \%$ of the global malaria burden [1].

According to the 2020 NMCP report, the trend of malaria cases reported by health facilities and community health workers was to increase by $4.0 \%$, from the previous $10,864,677$ in 2019 , to $11,331,009$ in 2020 . In Tete province, the trend of cases was also increased by $12.0 \%$, from 725,745 in 2019 , to 812,239 in 2020 . Regarding mortality, the trend was decreasing, from 1.4 deaths per 100,000 inhabitants in 2019 to 1.0 deaths per 100,000 inhabitants in 2020 [2].

The WHO recommends implementing malaria prevention strategies through vector control and chemoprevention in certain population groups [3]. In Mozambique, the primary malaria prevention strategy is vector control through universal coverage campaigns of insecticide-treated nets (ITN) and targeted indoor residual spraying (IRS).

Women of reproductive age, who are pregnant, are a high-risk group for malaria infection, and the consequences are maternal anaemia, placental parasitaemia, retardation of intrauterine growth of the fetus, preterm birth, and low birth weight [4]. So, for pregnant women, in addition to offering ITN at antenatal care (ANC) to maintain universal coverage, intermittent preventive treatment in pregnancy with sulfadoxinepyrimethamine (IPTp-SP) is also administered [5, 6].

According to the Mozambique Malaria Indicators Survey (MIS) from 2018, with the exception of Nampula province, less than half of women aged 15-49 years old had complete knowledge about the cause, symptoms, prevention and treatment of malaria. In Tete Province, only $46.0 \%$ of women had complete knowledge. Knowledge gaps existed between urban and rural with $87.0 \%$ of women in urban areas correctly reporting that sleeping under a mosquito net can protect against malaria, compared to $77.0 \%$ in rural areas. In the same survey, the number of women who received more than four doses of IPTp-SP was $30.8 \%$ in urban areas compared to $17.6 \%$ in rural areas, indicative of important differences in malaria knowledge and service access across urban/ rural zones [6].
Individual factors, such as age, education level, occupation, wealth index, may influence malaria knowledge [7-13]. Knowledge of the sociocultural aspects of communities is a key factor in the success of malaria prevention strategies and has been a major challenge of malaria control programmes which seek to improve communication strategies for behaviour change [6]. Knowledge about malaria by women can contribute to they take decisions about their own and children's health care seeking [14]. Stronger insights into factors associated with malaria knowledge, attitudes and practices is relevant for Mozambique to achieve the social and behaviour change (SBC) goal of the Malaria Strategic Plan: which is to ensure that $70.0 \%$ of people seek adequate and timely health care and at least $85.0 \%$ of the population uses an appropriate protection method by 2022 [5].

Evidence-based decision-making is one of the strategies of the Mozambique National Malaria Control Programme, yet there are few studies conducted to understand the level and the factors influencing knowledge about malaria, particularly in rural areas. To appropriately target messages and stratify populations in order to prevent malaria in women of reproductive age, it is necessary to identify the factors associated with knowledge about malaria, its cause, symptoms and prevention. This study aimed to assess factors associated with knowledge about malaria among women of reproductive age in Mágoe district, Tete province, in 2019.

\section{Methods}

\section{Study design and setting}

This analysis used data from a cross-sectional study that was intended to serve as the baseline of the study on "cost-effectiveness of malaria communication strategies on social and behavioural change", conducted in November 2019 in Mágoe district, Tete province in Mozambique. Magoe District has a population of 89,273 inhabitants, with a density population of 10.3 inhabitants per square kilometre, and is located in the southwest of Tete province, bordered to the north by Zumbo and Maravia districts, to the east and south by the Republic of Zimbabwe, and to the east with Cahora Bassa District $[15,16]$. Two administrative posts were included for the study, Mphende and Mucumbura. Mphende is the headquarters of the Mágoe district, and Mucumbura is located near the border with the Republic of Zimbabwe. The health services of Mucumbura, attend besides the population of Mozambique, the population of Zimbabwe. Mágoe district was selected because it had high malaria incidence with 27 cases per 1,000 habitants in the year 2019, has high community radio coverage, and was not covered by interpersonal communication malaria SBC interventions at the time of data collection. 


\section{Data collection}

Two structured questionnaires, a household questionnaire and a questionnaire for women of reproductive age (15-49 years old) were utilized. These questionnaires were based on the Malaria Behaviour Survey and MIS questionnaires and were tested in a rural area of Tete City to validate the questions and ensure its functionality and appropriateness for the local context. The questionnaires included questions related to socio-economic indicators, possession of ITN, history of fever in the past 2 weeks, history of recent travel, and current pregnancy, along with extensive questions on ideational factors associated with each key malaria behaviour (e.g. self-efficacy to use an ITN). Before the research began the interviewers were trained on the methods of obtaining consent and conducting the interviews. The interviewers were individuals with knowledge of the Cinyungwe, Shona, Tawala and Portuguese languages, as these are the most widely spoken languages in the region.

All enumeration areas in Mágoe District were eligible to be randomly selected for the study. Pre-existing lists of all enumeration areas (EA), including population size estimates and maps from Mozambique's National Institute of Statistics were used to develop a list of the EA to be selected for inclusion in the study. A sub-group of EA was selected in a manner designed to minimize bias by ensuring as much geographic separation of the EA as possible. Once selected, 120 EA were visited and fully enumerated. In each EA, 15 households were randomly selected. Households eligible for the study had to have one child under five years old and at least one mosquito net for every two residents under 5 years old.

\section{Study variables}

In this study, the following socio-demographic variables were analyzed: age $(15-19,20-24,25-29,30-34,35-39$, 40-44 and 45-49), place of residence (Mphende Locality /Mucumburra Locality), marital status (single/married), education level (none, primary, complete primary, secondary, secondary completed and above), literacy (does not read, read part of a sentence, read a whole sentence), number of births (none, 1 to 2, 3 to 4, 5 and more births), language used for the interview (Portuguese, English, Cinyungwe, Cyiau, other), exposure to malaria messages in the six months before the survey (yes/no) and wealth quintile (lowest, second lowest, middle, second highest, highest).

The variable complete knowledge about malaria was a composite variable composed of the following five variables: signs and symptoms of malaria, mode of transmission, prevention, treatment, and whether malaria is curable. For signs and symptoms, the woman had to answer fever as a symptom of malaria, for mode of transmission she had to answer mosquito bite, for prevention she had to refer to mosquito net treated or not with insecticide, and for malaria treatment the women had to indicate at least one antimalarial drug in order to be categorized as having complete malaria knowledge.

\section{Data analysis}

Weighted analyses were performed in the statistical program STATA 16.1 (StataCorp LLC., College Station, Texas). Sociodemographic and other characteristics were presented as percentages and frequencies. The assessment of factors associated with knowledge about malaria was through logistic regression and knowledge about malaria was considered as dependent variable. To measure complete knowledge about malaria, in yes/no, the woman had to answer five questions about malaria. If she answered all five questions correctly, she was considered to have complete knowledge about malaria, otherwise, she was not considered to have complete knowledge. Variables that were statistically significant (p-value $<0.05$ ) in the bivariate logistic regression analysis at $95.0 \%$ confidence interval $(\mathrm{CI})$ or considered important a priori based on existent literature, were included in the multivariate regression to calculate the adjusted odds ratio (aOR).

\section{Results}

\section{Characteristics of the participants}

Table 1 illustrates the sociodemographic characteristics of the women participating in the study. A total of 1923 women were interviewed in the study, of whom 24 were excluded because where aged equal or more than 50 years, and 1899 women aged $15-49$ years were eligible to the analysis, $68.0 \%$ were from Mucumburra. The mean age of the women was $27(\mathrm{SD} \pm 8.4)$ years. The highest proportion of women was $15-19$ years old, at $24.4 \%$ of the sample. Regarding marital status, $76.4 \%$ lived with a partner in their residence, and the rest were single. A total of $40.7 \%$ of participants had a primary school level education and $19.4 \%$ had no schooling. Only $31.8 \%$ were literate. Household ownership of goods that allow access to information was $32.6 \%$ for radio and $18.5 \%$ for television. Of all women, $86.5 \%$ had not heard or seen a message about malaria in the last six months before the interview. Regarding the number of births, the women have had in their lifetime, $30.5 \%$ had between one and two births, and $14.7 \%$ had no births. Of the total number of women surveyed, $83.5 \%$ of interviews were conducted in the Cinyungwe language, and $4.7 \%$ were done using 
Table 1 Distribution of sociodemographic and other characteristics of women of reproductive age in Magoe, Tete, 2019

\begin{tabular}{|c|c|c|}
\hline Characteristics & $\mathrm{N}=1899$ & $\%$ \\
\hline \multicolumn{3}{|l|}{ Group age } \\
\hline Mean (SD), in years & $27(8.4)$ & \\
\hline $15-19$ & 463 & 24.38 \\
\hline $20-24$ & 436 & 22.96 \\
\hline $25-29$ & 359 & 18.90 \\
\hline $30-34$ & 264 & 13.90 \\
\hline $25-39$ & 204 & 10.74 \\
\hline $40-44$ & 114 & 6.00 \\
\hline $45-49$ & 59 & 3.11 \\
\hline \multicolumn{3}{|l|}{ Marital status } \\
\hline Single & 448 & 23.59 \\
\hline Living with partner & 1451 & 76.41 \\
\hline \multicolumn{3}{|l|}{ Place of residence } \\
\hline Mphende & 605 & 31.86 \\
\hline Mucumburra & 1294 & 68.14 \\
\hline \multicolumn{3}{|l|}{ Level school } \\
\hline None & 369 & 19.43 \\
\hline Primary incomplete & 772 & 40.65 \\
\hline Primary complete & 336 & 17.69 \\
\hline Secondary & 331 & 17.43 \\
\hline Secondary complete or above & 91 & 4.79 \\
\hline \multicolumn{3}{|l|}{ Literacy } \\
\hline Does not read at all & 795 & 42.11 \\
\hline Read part of a sentence & 493 & 26.11 \\
\hline Read a whole sentence & 600 & 31.78 \\
\hline \multicolumn{3}{|l|}{ Number of Births } \\
\hline None & 279 & 14.69 \\
\hline 1 to 2 children & 674 & 35.49 \\
\hline 3 to 4 children & 570 & 30.02 \\
\hline 5 and more children & 376 & 19.80 \\
\hline \multicolumn{3}{|l|}{ Radio ownership } \\
\hline No & 1280 & 67.40 \\
\hline Yes & 619 & 32.60 \\
\hline \multicolumn{3}{|l|}{ Television ownership } \\
\hline No & 1548 & 81.52 \\
\hline Yes & 351 & 18.48 \\
\hline \multicolumn{3}{|c|}{ Exposure to malaria message in the last 6 months } \\
\hline No & 1642 & 86.47 \\
\hline Yes & 257 & 13.53 \\
\hline \multicolumn{3}{|l|}{ Wealth quintile } \\
\hline Lower & 428 & 22.54 \\
\hline Second & 334 & 17.59 \\
\hline Medium & 408 & 21.48 \\
\hline Fourth & 336 & 17.69 \\
\hline Highest & 393 & 20.70 \\
\hline
\end{tabular}

Portuguese. A total of $22.5 \%$ of women were in households from the lowest quintile.

\section{Distribution of knowledge of causes, symptoms, prevention and cure of malaria}

Table 2 illustrates that of all participants, 70.9\% recognized fever as a symptom of malaria, $91.8 \%$ knew that a mosquito bite is the way malaria is transmitted, and 93.9\% mentioned a mosquito net as the way to prevent malaria. A total of $91.5 \%$ knew that malaria is curable, however, $76.4 \%$ did not know of any anti-malarials. Significant differences in knowledge by administrative post existed for all questions, but did not exist for the complete knowledge.

\section{Characteristics of study participants by malaria knowledge level}

Of the women interviewed, $48.6 \%$ correctly answered all five questions of interest about malaria. The difference in the level of knowledge about the causes, transmission, symptoms and treatment of malaria among women (Table 3) was statistically significant among the different age groups $(\mathrm{p}=0.001)$, and among different levels of education, literacy, wealth quintiles, and in different languages used for interview $(\mathrm{p}<0.001)$, as well as the number of births $(\mathrm{p}=0.009)$, and television possession in the household $(p=0.008)$. No significant difference was noted by marital status $(\mathrm{p}=0.958)$, place of residence $(\mathrm{p}=0.209)$, radio possession in the household $(\mathrm{p}=0.593)$, or exposure to a malaria message in the last six months $(\mathrm{p}=0.593)$.

\section{Factors associated with complete malaria knowledge}

Table 4 presents the results of the models of factors associated with complete malaria knowledge. Compared with women aged 15-19 years, women in the age groups 30-34 $(\mathrm{aOR}=1.8,95 \% \mathrm{CI}=1.2-2.7)$ and $35-39$ $(\mathrm{aOR}=1.9,95 \% \mathrm{CI}=1.1-3.1)$ had significantly higher odds of having complete malaria knowledge. Having completed secondary school or above $(\mathrm{aOR}=2.5,95 \%$ $\mathrm{CI}=1.3-4.6)$, compared with women without any level of school education, and being able to read part of a sentence $(\mathrm{aOR}=1.7,95 \% \mathrm{CI}=1.3-2.1)$ were also associated with higher odds of complete malaria knowledge. The odds of having complete malaria knowledge were also significantly higher in women with $1-2$ or 3-4 children $(\mathrm{aOR}=1.8,95 \% \mathrm{CI}=1.2-2.6$, and $\mathrm{aOR}=1.7,95 \%$ 
Table 2 Participant's malaria knowledge causes, symptoms, prevention and cure by place of residence, Magoe, Tete, 2019

\begin{tabular}{|c|c|c|c|c|c|c|c|c|}
\hline \multirow[t]{3}{*}{ Knowledge } & \multicolumn{2}{|l|}{ Total } & \multicolumn{4}{|c|}{ Residence } & \multirow[t]{3}{*}{$x^{2}$} & \multirow[t]{3}{*}{$\mathrm{p}$-value } \\
\hline & \multirow[t]{2}{*}{$\mathrm{N}=1899$} & \multirow[t]{2}{*}{$\%$} & \multicolumn{2}{|c|}{ Mphende } & \multicolumn{2}{|c|}{ Mucumburra } & & \\
\hline & & & $n=605$ & $\%$ & $n=1294$ & $\%$ & & \\
\hline \multicolumn{9}{|c|}{ Fever is malaria symptom } \\
\hline No & 553 & 29.12 & 231 & 38.18 & 322 & 24.88 & 35.32 & $<0.001$ \\
\hline Yes & 1346 & 70.88 & 374 & 61.82 & 972 & 75.12 & & \\
\hline \multicolumn{9}{|c|}{ Mosquito bites transmit malaria } \\
\hline No & 155 & 8.16 & 62 & 10.25 & 93 & 7.19 & 5.15 & 0.023 \\
\hline Yes & 1744 & 91.84 & 543 & 89.75 & 1201 & 92.81 & & \\
\hline \multicolumn{9}{|c|}{ Mosquito nets prevent malaria } \\
\hline No & 116 & 6.11 & 50 & 8.26 & 66 & 5.10 & 7.19 & 0.007 \\
\hline Yes & 1783 & 93.89 & 555 & 91.74 & 1228 & 94.90 & & \\
\hline \multicolumn{9}{|c|}{ Malaria is curable } \\
\hline No & 91 & 4.79 & 49 & 8.10 & 42 & 3.25 & 21.30 & $<0.001$ \\
\hline Yes & 1738 & 91.52 & 534 & 88.26 & 1204 & 93.04 & & \\
\hline Don't know & 70 & 3.69 & 22 & 3.64 & 48 & 3.71 & & \\
\hline \multicolumn{9}{|c|}{ Able to list an antimalarial medicine } \\
\hline No & 410 & 23.59 & 89 & 16.67 & 321 & 26.66 & 20.50 & $<0.001$ \\
\hline Yes & 1328 & 76.41 & 445 & 83.33 & 883 & 73.34 & & \\
\hline \multicolumn{9}{|c|}{ Complete knowledge } \\
\hline No & 977 & 51.45 & 324 & 53.55 & 653 & 50.46 & 1.57 & 0.209 \\
\hline Yes & 922 & 48.55 & 281 & 46.45 & 641 & 49.54 & & \\
\hline
\end{tabular}

$\mathrm{CI}=1.0-2.6$, respectively), as compared to those with none and in those who had their interviews completed in Portuguese or Cinyungwe $(\mathrm{aOR}=2.3,95 \% \mathrm{CI}=1.3-4.1$, and $\mathrm{aOR}=2.1,95 \% \mathrm{CI}=1.5-2.8$, respectively), as compared to those interviewed in an "other" language.

In this study, exposure to a malaria message in the last six months $(\mathrm{aOR}=0.9,95 \% \mathrm{CI}=0.7-1.3)$, and possession of television in the household $(\mathrm{aOR}=0.9,95 \% \mathrm{CI}=0.6-$ 1.5) were not associated with complete knowledge about malaria.

\section{Discussion}

This study assessed the factors associated with complete malaria knowledge among women of reproductive age in a rural Mozambique district and found that less than half of the women had complete knowledge. This low knowledge, along with low reported access to malaria information are potentially indicative of limited dissemination of malaria prevention measures by the health personnel or by the community health worker, which is not consistent with WHO recommendations or NMCP plans [1,
5]. Women are important in influencing malaria prevention practices within the family and community, and can contribute to the dissemination and implementation of prevention measures within households $[17,18]$ so this relatively low knowledge is problematic.

In this study, education level was shown to be associated with women's knowledge about malaria, as women with lower education levels had lower odds of having complete malaria knowledge. Women in Mozambique with low education are mostly rural residents, where access to health care and information is low and they may travel long distances to seek health care [19]. Women with higher levels of education tend to have more access to information, knowledge, and decision-making power about their health status and are mostly urban residents [20]. Studies in countries have shown similar results regarding the comparison of knowledge about malaria prevention in pregnant and non-pregnant women, and others have shown that the higher a woman's level of education, the greater the chance of having more access to information and having malaria knowledge [17, 21, 22]. These results underscore the importance of the broader 
Table 3 Distribution of participants complete malaria knowledge according to sociodemographic characteristics, Mágoe District, 2019

\begin{tabular}{|c|c|c|c|c|c|}
\hline \multirow[t]{3}{*}{ Variables } & \multicolumn{2}{|c|}{ Malaria complete knowledge } & \multirow{3}{*}{$\begin{array}{l}\text { Total } \\
1899\end{array}$} & \multirow[t]{3}{*}{$x^{2}$} & \multirow[t]{3}{*}{$p$-value } \\
\hline & No n (\%) & Yes n (\%) & & & \\
\hline & $922(48.55)$ & $977(51.45)$ & & & \\
\hline \multicolumn{6}{|l|}{ Group age } \\
\hline $15-19$ & $269(58.10)$ & $194(41.90)$ & 463 & 22.8 & 0.001 \\
\hline $20-24$ & $218(50.00)$ & $218(50.00)$ & 436 & & \\
\hline $25-29$ & $186(51.81)$ & $173(48.19)$ & 359 & & \\
\hline $30-34$ & $117(44.32)$ & $147(55.68)$ & 264 & & \\
\hline $25-39$ & $89(43.63)$ & $115(56.37)$ & 204 & & \\
\hline $40-44$ & $69(60.53)$ & $45(39.47)$ & 114 & & \\
\hline $45-49$ & $29(49.14)$ & $30(50.85)$ & 59 & & \\
\hline \multicolumn{6}{|l|}{ Marital status } \\
\hline Single & $230(51.34)$ & $218(48.66)$ & 448 & 0.003 & 0.958 \\
\hline Married & $747(51.48)$ & $704(48.52)$ & 1451 & & \\
\hline \multicolumn{6}{|l|}{ Place of residence } \\
\hline Mphende & $324(53.55)$ & $281(46.45)$ & 605 & 1.6 & 0.209 \\
\hline Mucumburra & $653(50.46)$ & $641(49.54)$ & 1294 & & \\
\hline \multicolumn{6}{|l|}{ Level school } \\
\hline None & $221(59.89)$ & $148(40.11)$ & 369 & 33.1 & $<0.001$ \\
\hline Primary & $401(51.94)$ & $371(48.06)$ & 772 & & \\
\hline Primary complete & $171(50.89)$ & $165(49.11)$ & 336 & & \\
\hline Secondary & $159(48.04)$ & $172(51.96)$ & 331 & & \\
\hline Secondary complete or above & $25(27.47)$ & $66(72.53)$ & 91 & & \\
\hline \multicolumn{6}{|l|}{ Literacy } \\
\hline Does not read & $468(58.87)$ & $327(41.13)$ & 795 & 29.2 & $<0.001$ \\
\hline Read part of a sentence & $223(45.23)$ & $270(54.77)$ & 493 & & \\
\hline Read a whole sentence & $284(47.33)$ & $316(52.67)$ & 600 & & \\
\hline \multicolumn{6}{|l|}{ Number of births } \\
\hline None & $166(59.50)$ & $113(40.50)$ & 279 & 11.5 & 0.009 \\
\hline 1 to 2 children & $338(50.15)$ & $336(49.85)$ & 674 & & \\
\hline 3 to 4 children & $272(47.72)$ & $298(52.28)$ & 570 & & \\
\hline 5 and more children & $201(53.46)$ & $175(46.54)$ & 376 & & \\
\hline \multicolumn{6}{|l|}{ Radio ownership } \\
\hline No & $664(51.88)$ & $616(48.12)$ & 1280 & 0.3 & 0.593 \\
\hline Yes & $313(50.57)$ & $306(49.43)$ & 619 & & \\
\hline \multicolumn{6}{|l|}{ Television ownership } \\
\hline No & $819(52.91)$ & $729(47.09)$ & 1548 & 7.1 & 0.008 \\
\hline Yes & $158(45.01)$ & $193(54.99)$ & 351 & & \\
\hline \multicolumn{6}{|c|}{ Exposure to malaria message in the last 6 months } \\
\hline No & $848(51.64)$ & $794(48.36)$ & 1642 & 0.2 & 0.593 \\
\hline Yes & $129(50.19)$ & $128(49.81)$ & 257 & & \\
\hline \multicolumn{6}{|l|}{ Wealth quintile } \\
\hline Lowest & $252(58.88)$ & $176(41.12)$ & 428 & 20.4 & $<0.001$ \\
\hline Second & $176(52.69)$ & $158(47.31)$ & 334 & & \\
\hline Medium & $197(48.28)$ & $211(51.72)$ & 408 & & \\
\hline Fourth & $179(53.27)$ & $157(46.73)$ & 336 & & \\
\hline Highest & $173(44.02)$ & $220(55.98)$ & 393 & & \\
\hline
\end{tabular}


Table 3 (continued)

\begin{tabular}{|c|c|c|c|c|c|}
\hline \multirow[t]{3}{*}{ Variables } & \multicolumn{2}{|c|}{ Malaria complete knowledge } & \multirow{3}{*}{$\begin{array}{c}\text { Total } \\
1899\end{array}$} & \multirow[t]{3}{*}{$x^{2}$} & \multirow[t]{3}{*}{ p-value } \\
\hline & No n (\%) & Yes n (\%) & & & \\
\hline & $922(48.55)$ & $977(51.45)$ & & & \\
\hline \multicolumn{6}{|c|}{ Language of interview } \\
\hline Portuguese & $37(41.57)$ & $52(58.43)$ & 89 & 26.5 & $<0.001$ \\
\hline English & $2(100.00)$ & $0(0.00)$ & 2 & & \\
\hline Cinyungwe & 791 (49.91) & 794 (50.09) & 1585 & & \\
\hline Ciyau & $2(100.00)$ & $0(0.00)$ & 2 & & \\
\hline Other & $145(65.61)$ & $76(34.39)$ & 221 & & \\
\hline
\end{tabular}

educational and development context in malaria knowledge and behaviours and suggest that malaria prevention should be viewed in a transdisciplinary way.

This study also found that malaria knowledge was higher among women who spoke the national language or the dominant local language. It is a positive finding that information is reaching those who speak this dominant local language, but in a country such as Mozambique where there are over forty languages and only one official national language, Portuguese, this study shows that those who speak non-dominant local languages may represent a demographic with persistent information needs. Engagement with local leaders to better target and reach such women might be an effective strategy. For the wealth quintile, the middle quintile was associated with complete knowledge about malaria. This result was different from other studies, in which the highest wealth quintile was most associated with complete knowledge about malaria [18]. The influence of the wealth quintile not only depends on the availability of assets in the household but also on the relationship between the owner of those assets and the woman [23]. These differences may be due to the residence of the women, as this study was conducted in a predominantly rural area while the others compared rural and urban areas. Rural regions have the highest prevalence of malaria, and are the places where prevention activities must be most focused [6]. One important information source is during ANC service delivery which is generally accessed across the different socioeconomic groups and may explain this finding and the fact that women with more children were significantly more likely to have complete malaria knowledge $[17,24]$.

In the bivariate analysis, an association between the ownership of a television and knowledge about malaria was observed. Access to malaria information, through radio and television, has been shown to have good results in the implementation of malaria prevention measures, as seen in sub-Saharan African countries [25]. However, more in-depth studies could be conducted to find out which television channels are used the most in the location studied.

An interesting finding is the no association between hearing malaria message in the last six months and complete knowledge about malaria. The messages about malaria are disseminated through different strategies, in the ANC, through the community engagement, by community volunteers for dissemination of key messages about malaria [26]. Exposure to malaria messages, and their influence on the use of malaria prevention measures, is not always similar in studies [27]. In other studies, exposure to malaria messages to the community has been shown to be a positive factor in the implementation of malaria prevention measures [28]. This finding shows that malaria messages may not be being disseminated equally, or there may be a need to improve existing strategies.

\section{Limitations}

This study design and inclusion criteria introduced a few limitations to the present analysis. Study inclusion was based on the existence of at least one child of five years of age or younger and at least one mosquito net per every two children in the household. These criteria meant that the population inherently had accessed a net in some way which may have contributed to their knowledge.

\section{Conclusions}

In this rural setting in highly endemic Mozambique, complete malaria knowledge among women of reproductive age remained low and was significantly lower in more vulnerable populations, suggesting that efforts to disseminate malaria prevention key messages to women should involve more stakeholders to effectively target 
Table 4 Factors associated with malaria complete knowledge by women of reproductive age, Mágoe District, 2019

\begin{tabular}{|c|c|c|c|c|}
\hline \multirow[t]{2}{*}{ Variables } & \multicolumn{2}{|l|}{ Bivariate } & \multicolumn{2}{|l|}{ Multivariate } \\
\hline & OR (IC95\%) & p-value & aOR (IC95\%) & $p$-value \\
\hline \multicolumn{5}{|l|}{ Group age } \\
\hline $15-19$ & Ref & - & Ref & - \\
\hline $20-24$ & $1.4(1.1-1.8)$ & 0.015 & $1.2(0.9-1.6)$ & 0.239 \\
\hline $25-29$ & $1.3(0.9-1.7)$ & 0.072 & $1.2(0.8-1.7)$ & 0.324 \\
\hline $30-34$ & $1.7(1.3-2.4)$ & $<0.001$ & $1.8(1.2-2.7)$ & 0.009 \\
\hline $35-39$ & $1.8(1.3-2.5)$ & 0.001 & $1.9(1.2-3.1)$ & 0.004 \\
\hline $40-44$ & $0.9(0.6-1.4)$ & 0.638 & $1.1(0.6-1.9)$ & 0.707 \\
\hline $45-49$ & $1.4(0.8-2.5)$ & 0.193 & $1.7(0.9-3.1)$ & 0.123 \\
\hline \multicolumn{5}{|l|}{ Marital status } \\
\hline Single & Ref & - & - & - \\
\hline Married & $0.9(0.8-1.2)$ & 0.958 & - & - \\
\hline \multicolumn{5}{|l|}{ Place of residence } \\
\hline Mphende & Ref & - & - & - \\
\hline Mucumbura & $1.1(0.9-1.4)$ & 0.209 & - & - \\
\hline \multicolumn{5}{|l|}{ Level school } \\
\hline None & Ref & - & Ref & - \\
\hline Some primary & $1.4(1.1-1.8)$ & 0.012 & $1.1(0.8-1.4)$ & 0.666 \\
\hline Primary complete & $1.4(1.1-1.9)$ & 0.016 & $0.9(0.7-1.4)$ & 0.887 \\
\hline Some secondary & $1.6(1.2-2.2)$ & 0.002 & $1.1(0.7-1.8)$ & 0.547 \\
\hline Secondary complete or above & $3.9(2.4-6.5)$ & $<0.001$ & $2.5(1.3-4.6)$ & 0.005 \\
\hline \multicolumn{5}{|l|}{ Literacy } \\
\hline Does not read & Ref & - & Ref & - \\
\hline Read part of a sentence & $1.7(1.4-2.2)$ & $<0.001$ & $1.7(1.3-2.1)$ & $<0.001$ \\
\hline Read a whole sentence & $1.6(1.3-2.0)$ & $<0.001$ & $1.3(0.9-1.8)$ & 0.122 \\
\hline \multicolumn{5}{|l|}{ Number of births } \\
\hline None & Ref & - & Ref & - \\
\hline 1 to 2 children & $1.5(1.1-1.9)$ & 0.009 & $1.8(1.2-2.6)$ & 0.003 \\
\hline 3 to 4 children & $1.6(1.2-2.1)$ & 0.001 & $1.7(1.0-2.6)$ & 0.031 \\
\hline 5 and more children & $1.3(0.9-1.8)$ & 0.124 & $1.3(0.8-2.1)$ & 0.378 \\
\hline \multicolumn{5}{|l|}{ Radio ownership } \\
\hline No & Ref & - & - & - \\
\hline Yes & $1.1(0.9-1.3)$ & 0.593 & - & - \\
\hline \multicolumn{5}{|l|}{ Television ownership } \\
\hline No & Ref & - & Ref & - \\
\hline Yes & $1.4(1.1-1.7)$ & 0.008 & $0.9(0.6-1.5)$ & 0.792 \\
\hline \multicolumn{5}{|c|}{ Exposure to malaria message in the last 6 months } \\
\hline No & 1 & - & Ref & - \\
\hline Yes & $1.1(0.8-1.4)$ & 0.665 & $0.9(0.7-1.3)$ & 0.733 \\
\hline \multicolumn{5}{|l|}{ Wealth quintile } \\
\hline Lower & Ref & - & Ref & - \\
\hline Second & $1.3(0.9-1.7)$ & 0.088 & $1.2(0.9-1.6)$ & 0.253 \\
\hline Medium & $1.5(1.2-2.0)$ & 0.002 & $1.5(1.1-2.1)$ & 0.005 \\
\hline Fourth & $1.3(0.9-1.7)$ & 0.121 & $1.2(0.9-1.7)$ & 0.185 \\
\hline Highest & $1.8(1.4-2.4)$ & $<0.001$ & $1.6(0.9-2.7)$ & 0.051 \\
\hline \multicolumn{5}{|l|}{ Language of interview } \\
\hline Portuguese & $2.7(1.6-4.4)$ & $<0.001$ & $2.3(1.3-4.1)$ & 0.004 \\
\hline English & 1 & - & 1 & - \\
\hline Cinyungwe & $1.9(1.4-2.6)$ & $<0.001$ & $2.1(1.5-2.8)$ & $<0.001$ \\
\hline
\end{tabular}


Table 4 (continued)

\begin{tabular}{|c|c|c|c|c|}
\hline \multirow[t]{2}{*}{ Variables } & \multicolumn{2}{|l|}{ Bivariate } & \multicolumn{2}{|l|}{ Multivariate } \\
\hline & OR (IC95\%) & p-value & aOR (IC95\%) & p-value \\
\hline Ciyau & 1 & - & 1 & - \\
\hline Other & Ref & - & Ref & - \\
\hline
\end{tabular}

and implement SBC interventions. The lower access in younger women without children show the need for interventions to be targeted outside of ANC delivery such as in schools. Women of reproductive age are critical target populations for malaria prevention efforts and mapping and responding to these malaria information gaps can help improve individual and familial health.

\section{Abbreviations}

ANC: Antenatal Care; aOR: Adjusted Odds Ratio; CDC: Centers for Disease Control and Prevention; Cl: Confidence Interval; EA: Enumeration Areas; IPTp-SP: Intermittent Preventive Treatment in Pregnancy with SulfadoxinePyrimethamine; IQR: Inter-Quartile Range; IRS: Indoor Residual Spraying; ITN: Insecticide-Treated Net; MIS: Malaria Indicators Survey; OR: Odds Ratios; SBC: Social and Behaviour Change; WHO: World Health Organization.

\section{Acknowledgements}

We would like to express special gratitude to the National Malaria Control Program for the opportunity to be part of the parent study

\section{Authors' contributions}

GA conceived and designed the study, and data analysis; EVR and CSB supervised and reviewed the data analysis; AS and RZ mentored in the elaboration of the manuscript. All authors contributed to the writing of the final manuscript. All authors read and approved the final manuscript.

\section{Funding}

This study was funded by the United States President's Malaria Initiative (PMI). Its contents are the sole responsibility of the authors, and do not necessarily represent the official position of the funding agencies.

\section{Availability of data and materials}

The datasets for this study are available upon a reasonable request.

\section{Declarations}

\section{Ethics approval and consent to participate}

The main study was approved by the National Bioethics in Health Committee, in Mozambique, number 62/CNBS/2019. It was reviewed and determined to be human subjects research with non-engagement of Centers for Disease Control and Prevention (CDC) staff by the CDC.

\section{Consent for publication}

Not applicable.

\section{Competing interests}

The authors declare that they have no competing interests.

\section{Author details}

${ }^{1}$ Mozambique Field Epidemiology Training Programme, Instituto Nacional de Saúde, P.O. Box 264, Maputo, Mozambique. ${ }^{2}$ MassGenics, Assigned for Centers for Disease Control and Prevention, Maputo, Mozambique. ${ }^{3}$ National Institute of Health, Maputo, Mozambique. ${ }^{4}$ National Malaria Control Programme, Ministry of Health, Maputo, Mozambique. ${ }^{5}$ United States President's Malaria
Initiative, USAID, Maputo, Mozambique. ${ }^{6}$ United States President's Malaria Initiative, USAID, Washington, D.C., USA.

Received: 28 September 2021 Accepted: 16 February 2022

Published online: 05 March 2022

References

1. WHO. World Malaria Report 2020. Geneva, World Health Organization, 2020. https://www.who.int/teams/global-malaria-programme/reports/ world-malaria-report-2020. Accessed 10 Dec 2020.

2. Ministério da Saúde. Programa Nacional de Controlo da Malária. In: Relatório Anual da Malaria 2020. Maputo, Moçambique, 2021.

3. WHO. Global technical strategy for malaria 2016-2030. Geneva: World Health Organization; 2015. p. 1-35. http://apps.who.int/iris/bitstream/ 10665/176712/1/9789241564991_eng.pdf?ua=1. Accessed 10 Dec 2020.

4. Meremikwu M, Ezedinachi E, Ehiri JE. Malaria in women and children. In: Maternal and Child Health: Global Challenges, Programs, and Policies. Springer, Boston, MA; 2009. p. 205-23. https://link.springer.com/ chapter/https://doi.org/10.1007/b106524_12

5. Ministério da Saúde. Programa Nacional de Controlo da Malária. In: Plano Estratégico da Malária 2017-2022. Maputo, Moçambique, 2018.

6. Instituto Nacional de Saúde, Instituto Nacional de Estatistica, Programa Nacional de controlo da Malária I. In: Inquérito Nacional sobre Indicadores de Malária (IIM) 2018. Maputo, Moçambique. Rockville, USA; 2019. https://dhsprogram.com/publications/publication-mis33-mis-final-repor ts.cfm. Accessed 9 Nov 2020.

7. Eisele TP, Keating J, Littrell M, Larsen D, Macintyre K. Assessment of insecticide-treated bednet use among children and pregnant women across 15 countries using standardized national surveys. Am J Trop Med Hyg. 2009;80:209-14

8. Toé LP, Skovmand O, Dabiré KR, Diabaté A, Diallo Y, Guiguemdé TR, et al. Decreased motivation in the use of insecticide-treated nets in a malaria endemic area in Burkina Faso. Malar J. 2009:8:175.

9. Belay M, Deressa W. Use of insecticide treated nets by pregnant women and associated factors in a pre-dominantly rural population in northern Ethiopia. Trop Med Int Health. 2008;13:1303-13.

10. Alaii JA, Hawley WA, Kolczak MS, Ter Kuile FO, Gimnig JE, Vulule JM, et al. Factors affecting use of permethrin-treated bed nets during a randomized controlled trial in Western Kenya. Am J Trop Med Hyg. 2003;68:137-41.

11. Graves PM, Ngondi JM, Hwang J, Getachew A, Gebre T, Mosher AW, et al. Factors associated with mosquito net use by individuals in households owning nets in Ethiopia. Malar J. 2011;10:354.

12. Noor AM, Mutheu JJ, Tatem AJ, Hay SI, Snow RW. Insecticide-treated net coverage in Africa: mapping progress in 2000-07. Lancet. 2009;373:58-67.

13. Koenker H, Kilian A. Recalculating the net use gap: A multi-country comparison of ITN use versus ITN access. PLoS ONE. 2014:9:e97496.

14. Ayanore MA, Tetteh J, Ameko A, Axame WK, Alhassan RK, Adoliba Ayanore A, et al. Reproductive-age women's knowledge and care seeking for malaria prevention and control in Ghana: analysis of the 2016 Malaria Indicator Survey. J Trop Med. 2019;2019:2316375.

15. Ministério da Administração Estatal. Perfil do Distrito de Mágoe Província de Tete. Edição 200. Moçambique, 2005.

16. Instituto Nacional de Estatistica. Folheto Distrital de Tete 2019. Moçambique. http://www.ine.gov.mz/estatisticas/publicacoes/folheto-distrital/ 
tete/folheto-distrital-de-tete_2019.pdf/view?searchterm=folheto+tete. Accessed 2 Feb 2022.

17. Yaya S, Bishwajit G, Ekholuenetale M, Shah V, Kadio B, Udenigwe O. Knowledge of prevention, cause, symptom and practices of malaria among women in Burkina Faso. PLoS ONE. 2017;12:e0180508.

18. Njau JD, Stephenson R, Menon MP, Kachur SP, McFarland DA. Investigating the important correlates of maternal education and childhood malaria infections. Am J Trop Med Hyg. 2014;91:509-19.

19. Sixpence A, Nkoka O, Nkoka O, Chirwa GC, Milanzi EB, Milanzi EB, et al. Levels of knowledge regarding malaria causes, symptoms, and prevention measures among Malawian women of reproductive age. Malar J. 2020;19:225.

20. Escamilla V, Calhoun L, Winston J, Speizer IS. The role of distance and quality on facility selection for maternal and child health services in urban Kenya. J Urban Health. 2018;95:1-12.

21. Castillo-Riquelme M, Mclntyre D, Barnes K. Household burden of malaria in South Africa and Mozambique: is there a catastrophic impact? Trop Med Int Health. 2008;13:108-22.

22. Oladimeji KE, Tsoka-Gwegweni JM, Ojewole E, Yunga ST. Knowledge of malaria prevention among pregnant women and non-pregnant mothers of children aged under 5 years in Ibadan. South West Nigeria Malar J. 2019;18:92.

23. Howe LD, Galobardes B, Matijasevich A, Gordon D, Johnston D, Onwujekwe $\mathrm{O}$, et al. Measuring socio-economic position for epidemiological studies in low-and middle-income countries: a methods of measurement in epidemiology paper. Int J Epidemiol. 2012;41:871-86.

24. Arnaldo P, Cambe MI, Magaço A, Chicumbe S, Rovira-Vallbona E, RosanasUrgell A, et al. Access to and use of preventive intermittent treatment for Malaria during pregnancy: A qualitative study in the Chókwè district. Southern Mozambique PLoS One. 2019;14:e0203740.

25. Yaya S, Uthman OA, Amouzou A, Bishwajit G. Mass media exposure and its impact on malaria prevention behaviour among adult women in subSaharan Africa: results from malaria indicator surveys. Glob Health Res Policy. 2018;3:20.

26. Malaria Consortium. Mobilizando as comunidades para a prevenção da malária em Moçambique. https://www.malariaconsortium.org/resou rces/publications/1082/mobilizando-as-comunidades-para-a-preven--oda-mal-ria-em-mo-ambique. Accessed 3 Feb 2022.

27. Keating J, Hutchinson P, Miller JM, Bennett A, Larsen DA, Hamainza B, et al. A quasi-experimental evaluation of an interpersonal communication intervention to increase insecticide-treated net use among children in Zambia. Malar J. 2012;11:313.

28. Owusu Adjah ES, Panayiotou AG. Impact of malaria related messages on insecticide-treated net (ITN) use for malaria prevention in Ghana. Malar J. 2014;13:123.

\section{Publisher's Note}

Springer Nature remains neutral with regard to jurisdictional claims in published maps and institutional affiliations.

Ready to submit your research? Choose BMC and benefit from:

- fast, convenient online submission

- thorough peer review by experienced researchers in your field

- rapid publication on acceptance

- support for research data, including large and complex data types

- gold Open Access which fosters wider collaboration and increased citations

- maximum visibility for your research: over 100M website views per year

At BMC, research is always in progress.

Learn more biomedcentral.com/submissions 